UDC 821.161.1.09 Čajanov A. V. https://doi.org/10.18485/ms_zmss.2020.98.3

\author{
Наталья Михаленко \\ Институт мировой литературы имени А. М. Горького РАН \\ tinril@1ist.ru
}

Natal'ya Mihalenko

A. M. Gorky Institute of World Literature of the RAS

tinril@1ist.ru

\title{
УСАДЬБА В ТВОРЧЕСТВЕ А. В. ЧАЯНОВА - ЛИТЕРАТУРНОЕ И РЕАЛЬНОЕ 1
}

\section{ESTATE IN THE WORK OF ALEXANDER CHAANOV - THE LITERARY AND THE REAL}

«Усадебный» текст в литературном творчестве А. В. Чаянова, всемирного признанного ученого-экономиста, глубоко связан с его научной, общественной и искусствоведческой работой. Сотрудничество в «Комитете по охране художественных сокровищ», деятельность которого была направлена на сохранение культурного достояния бывших дворянских усадеб; внимание к истории поместья «Петровско-Разумовское», в котором была организована Сельскохозяйственная академия, где работал Чаянов, а также обсуждение футурологических проектов, связанных с подмосковной усадьбой Архангельское, вероятно, впоследствии повлияли на складывание художественного образа монастыря-университета «братства Флора и Лавра» в Путешествии моего брата Алексея в страну крестьянской утопии. На материале литературного текста получили воплощение идеи Чаянова об идеальной организации жизни и деятельности, которая им сопрягалась с образом «помещичьей культуры» двадцатых годов XIX века, а также профессионального образования, связанного также с совершенствованием в различных видах искусства.

Ключевые слова: А. В. Чаянов, «усадебный» текст, Путешествие моего брата Алексея в страну крестьянской утопии, утопия, усадьба Петровско-Разумовское.

The so-called "estate" text from the writings of Alexander Chayanov, a world-class economist, is deeply rooted in his scientific, social, and art studies work. His cooperation with the "Committee for the Preservation of Treasures of Art", targeted at the preservation of the artistic heritage of the old estate houses that used to belong to the nobility,

1 Исследование выполнено в ИМЛИ РАН за счет гранта Российского научного фонда (проект № 18-18-00129) «Русская усадьба в литературе и культуре: отечественный и зарубежный взгляд». 
the high attention he paid to the history of the "Petrovsko-Razumovskoye" estate eventually turned into the Moscow Agricultural Academy where Chayanov used to work, as well as discussions of futuristic projects related to the Arkhangelskoye estate located near Moscow - all these factors probably contributed to the image of the "Brotherhood of St. Florus and Laurus", a monastic type of university, found in his My Brother Alexei's Journey into the Land of Peasant Utopia. This artistic writing became the means of implementation of Chayanov's ideas about the perfect organization of life and work, seen by him in conjunction with the "culture of the nobility" of the 1820 s, and of the professional education that also included acquiring skills in different kinds of art.

Key words: A. V. Chayanov, The Journey of My Brother Alexei to the Land of Peasant Utopia, "estate" text, the Utopia, the Petrovsko-Razumovskoye estate.

В творчестве известного экономиста и писателя А. В. Чаянова интерес к истории предыдущих эпох особенно сильно проявился не только в его краеведческих и москвоведческих работах, но и в литературных произведениях. Исследование усадебной жизни, бережное сохранение устоев прошлого становится одним из своеобразных семантических центров его работы и литературной деятельности. Здесь соединяется интерес Чаянова как выдающегося ученого и историка, стремящегося в своем путеводителе «Петровское-Разумовское» и романе Путешествие моего брата Алексея в страну крестьянской утопии воссоздать усадебный быт прошлых эпох, где деятельность человека была гармонично связана с природными циклами, и писателя, который хочет понять особенности творчества авторов XIX века, жизнь многих из которых была связана с родовыми имениями.

«Усадебная» тема у Чаянова складывается из нескольких составляющих - это его интерес к истории Москвы, работа в «Комитете по охране художественных сокровищ», связанная с его научной деятельностью по изучению кооперации; воссоздание в повестях и утопии жизни в поместье.

В феврале 1918 года Всероссийский кооперативный съезд вынес постановление, призывавшее кооперативные союзы к организации охраны культурно-художественных памятников России и к созданию особого фонда охраны расхищаемых художественных сокровищ: «Мы будем следить за сокровищами искусства, картинами, библиотеками и спасать их от гибели, помещая в местные и центральные музеи, иначе они будут за бесценок скуплены торговцами и увезены за границу. <..> неужели Россия новая, русский свободный народ, получивший это ценное наследие, не сумеет сберечь его, даст расхитить и не в силах будет продолжить культурную работу старой России» (Краткий отчет 1919: 69).

Комитет по охране художественных сокровищ был создан кооперативным съездом в разгар Гражданской войны, когда разорялись бывшие дворянские усадьбы, уничтожались собранные там произведения искусства, разрывалась связь поколений. Возглавляли эту работу И. Э. Грабарь (председатель), П. П. Муратов (комиссия приобретений), Н. И. Романов 
(музейная комиссия), А. В. Чаянов (комиссия просветительная), Б. С. Боднарский (комиссия библиотечная), В. В. Хижняков (комиссия финансовая), А. М. Эфрос (секретарь) и др.

Деятельность Комитета помогла спасти от расхищения из разоренных усадеб и передать в Румянцевский музей и в Третьяковскую галерею «работы Венецианова, Иванова, К. Дольчи, Кипренского, Пиранези, Рекко, Хондиуса, Борисова-Мусатова, Дюжардена и многих других мастеров старой Европы» (Чаянов 1919: 16). В Румянцевский музей был передан «Альбом Ушаковой» (Е. Н. Ушаковой) с многочисленными рисунками и записями А. С. Пушкина.

В работе Комитета задачи охраны искусства были тесно связаны с повышением художественной культуры в стране, искусствоведческой образованностью населения. Для этого предпринимались следующие шаги: «1) популяризация искусства при помощи изданий курсов (для инструкторов), чтений, выставок, экскурсий, 2) собирание и охрана от грозящей им опасности культурно-художественных ценностей на местах, 3) приобретение выдающихся произведений искусства для пополнения музеев, 4) образование на местах музеев и хранилищ и установление связи с существующими местными учреждениями такого рода» (Романов 1919: 21-22).

В статье «Искусство и кооперация» Н. И. Романов отмечал, что «великой ценности искусства не чувствовал, не понимал да и не мог понять крестьянин, громивший помещичьи усадьбы в роковой в истории России 1917 год. Картины, скульптура, старинная мебель, музыкальный инструмент, книги, - все это для крестьянина не ценности духовные, а лишь типичные черты чуждого ему помещичьего быта. Крестьянин жег и разрушал эти предметы, не подозревая, что губит духовные сокровища России, свои собственные и своих детей...» (Романов 1919: 17).

Чаянов высоко ставил ценность материального и духовного наследия русской усадебной культуры. Направления работы Комитета, некоторые ее итоги и находки получили отражение в его статьях и Путешествии...

В утопической стране Чаянова нет урбанизации в привычном нам виде: «Город казался сплошным парком, среди которого архитектурные группы возникали направо и налево, походили на маленькие затерявшиеся городки» (Чаянов 2006в: 229). В своей утопии он создал идеальную картину гармоничного сосуществования человека и природы. Еще в статье «Парки и аграрная реформа» писатель говорил о важности эстетических ценностей в крестьянском быту, которые помогают возрождению деревни. Он ратовал за то, чтобы многие выдающиеся усадебные парки были не только сохранены с целью организации в них санаториев и лечебниц, но и получили бы статус общественного художественного достояния. И здесь Чаянов имел в виду как парки в Кусково и Архангельском, «представляющие собой европейски известные музеи, или как Ярополец и Ясная Поляна, освященные именами Пушкина и Толстого», 
так и «даже более скромные парковые насаждения, имеющие эстетическую ценность». (Чаянов 2008а: 109).

В стране утопии «помещичья культура двадцатых годов прошлого века, давшая декабристов и подарившая миру Пушкина» (Чаянов 2006в: 262) признается эталонной, наиболее способствующей всестороннему развитию человека. По мысли Чаянова, в усадебном быту было представлено идеальное соединение практической работы, сельского труда и бережного сохранения культурного наследия предшествующих эпох. Семья утопических жителей - Мининых, принимавших крупного советского работника периода революции Алексея Кремнева, который фантастическим образом перенесся в будущее и вынужден был выдавать себя за американского экономиста Чарли Мена, живет в «нескольких маленьких домиках, построенных в простых формах XVI века и обнесенных тыном, придававшим усадьбе вид древнего городка» (Чаянов 2006в: 238).

В основе утопического хозяйственного строя, вопреки идеям коллективизации, реализовывавшимся в 1920-1930-х годах, лежит индивидуальный крестьянский труд, который считается «совершеннейшим типом хозяйственной деятельности»: «Наши урожаи, дающие свыше 500 пудов с десятины, получаются чуть ли не индивидуализацией ухода за каждым колосом» (Чаянов 2006в: 238). В таком труде «человек противопоставлен природе», приходит в творческое соприкосновение со всеми силами космоса и создает новые формы бытия. Каждый работник творец, каждое проявление его индивидуальности - искусство труда» (Чаянов 2006в: 245).

В жизни утопических жителей искусству уделяется особое место. В современных им представлениях не забыты традиции прошлого «властителем мировых помыслов сделались суздальские фрески XII века, и наступило царство реализма с Питером Брейгелем как кумиром» (Чаянов 2006в: 228). Рассуждения о философии творчества, теургии занимают молодых людей - так, Параскева Минина «с жаром юношеского увлечения повествовала о своих любимых мастерах: старом Брейгеле, Ван Гоге, старике Рыбникове и великолепном Ладонове. Пламенная поклонница неореализма, она искала в искусстве тайны вещей, чего-то или божеского или дьявольского, но превышающего силы человеческие» (Чаянов 2006в: 227). Девушки-подростки создают своеобразные картины - стилизуют поданные на ужин блюда в стиле натюрмортов голландских живописцев и требуют Алексея оценить их труды: «На его компетентное решение были представлены два плоских блюда: одно декорированное раками и черным виноградом, а другое представляющее композицию из лимона, красного винограда и граненого бокала с вином. Две конкурентки, Мэг и Наташа, со всей звонкостью своих пятнадцатилетних голосов требовали решить, чей натюрморт “голландее”. С трудом выйдя из затруднения и признав одну композицию забытым оригиналом Якова Путера, а другую плагиатом с Вилема Кольфа...» (Чаянов 2006в: 
240). В лучших традициях усадебного времяпрепровождения для гостя из Америки поют романсы. Такая широкая дискуссия об искусстве в утопическом обществе неслучайна, поскольку для этого создаются все условия.

В стране будущего функционируют передвижные выставки музеев, особенно ценные экспонаты «гастролируют» по разным городам. На ярмарке в Белой Колпи Кремнев видит работы «Венецианова, Кончаловского, “Святого Герасима" рыбниковской кисти, новгородского "Илью" Остроуховского собрания и сотни новых незнакомых картин и скульптур», он останавливается перед «“Христом отроком” Джампетрино» (Чаянов 2006в: 255). Крестьянство, которое во время революций и Гражданской войны разрушало старинные усадьбы, в стране утопии стремится повышать свою искусствоведческую образованность - в этом убеждает «энергия, с которой раскупались... 132-е издание книги П. Муратова "История живописи на ста страницах"2 и книжка "От Рокотова до Ладонова"» (Чаянов 2006в: 255). Социальный прогресс на уровне государственной власти понимается как расширение «круга лиц, пьющих из первоисточника жизни и культуры» (Чаянов 2006в: 260). В зале реликвий Румянцевского музея Алексей видит «Ушаковский альбом» с автографами Пушкина, незадолго до публикации Путешествия... переданный туда кооперативным комитетом.

Характерно, что о необходимости такого культурного развития крестьянских масс Чаянов писал в статье «Парки и аграрная реформа», где отмечал восприимчивость сельских жителей к искусству: «Народные дома, основанные кооперативными комитетами, насчитываются сотнями, <... у успех у крестьянской аудитории "Царя Эдипа" и "Бориса Годунова" свидетельствует о серьезности подхода к театру; хоровые общества имеют у нас уже некоторую историю, а кооперативная пресса отметила даже случаи передвижных художественных выставок» (Чаянов 2008a: 109).

Важным в понимании писателем усадебной культуры является образ утопического светского монастыря «братство Флора и Лавра», устроенного в подмосковной усадьбе Архангельское, «братья коего вербовались среди талантливых юношей и девушек, выдвинувшихся в искусствах и науках» (Чаянов 2006в: 237). Истоком данного образа, видимо, является преобразование усадьбы Петровско-Разумовское в Петровскую земледельческую и лесную академию, а впоследствии в Сельскохозяйственную академию имени К. А. Тимирязева ${ }^{3}$, где работал и преподавал ученый.

2 Такой книги у П. П. Муратова нет, но по тому, что в утопическом обществе раскупается ее очередной тираж, можно судить о значении, которое Чаянов придавал искусствоведческим работам исследователя и коллеги по работе в кооперативном комитете.

3 Как писал Чаянов, это было «высшее научное учреждение СССР в деле изучения сельского хозяйства, собравшее в своих музеях, лабораториях, библиотеках, научных 
Чаянов также мог быть знаком с различными проектами, связанными с общественным использованием усадьбы Архангельское.

Рассказу о Сельскохозяйственной академии Чаянов отводит видное место в своих статьях о Москве - «Петровско-Разумовское в его прошлом и настоящем», посвящает стихотворение «Приглашение в Петровку» в «Лёлиной книжке»: «Прошу ко мне, когда не прочь Вы/Со мной Петровку посетить. / В полях, на глыбах черной почвы/Сереет паутины нить. // На синем небе чертят клены / Узор желтеющей листвы, / И солнца отблеск отраженный/ Ложится на простор травы. // В аллеях листья старой липы / Настлали сказочный ковер. / В теплицах поздние тюлипы/Еще ласкать умеют взор» (Чаянов 2006а: 25). Часто в своих лирических стихах он писал о красотах этого усадебного парка, его умиротворяющих пейзажах.

Рядом с Петровской академией сохранились «остатки подмосковного имения Кирилла Разумовского» со «старинной церковью, некоторыми... постройками и прекрасным парком, сильно запущенным, но сохранившим в себе всю прелесть и великолепие садовых насаждений XVIII века» (Чаянов 2008б: 24). Вероятно, такая близость подмосковного поместья и учебного заведения подтолкнула Чаянова к созданию образа «светского монастыря», университета, который был бы расположен на территории старинной усадьбы, где сельскохозяйственные работы сочетались бы с постижением наук и искусств. Вот как о такой трансформации реальной усадьбы писал Чаянов: «Пять лет подмосковная Разумовских приспособлялась к открытию высшей школы; перестраивались старые здания, воздвигались новые, проводились шоссейные дороги, разбивались цветники. Варгас-де-Бедемар устраивал лесную дачу, в коровниках и стойлах размещался вновь купленный альгаузский скот и арденские лошади, Стебутом создавался сельско-хозяйственный музей...» (Чаянов 2008б: 28).

В статье «Методы высшего образования» (1919) Чаянов также писал о необходимости создания «закрытых школ-монастырей - замкнутых общин мастеров науки и учеников» (Чаянов 2006б: 640), где были бы созданы все условия для передачи знаний в совместной работе от профессоров к одаренным студентам.

В Путешествии... создана художественная модель такого учебного заведения. Студенты получают здесь разностороннее образование: «Братство владело двумя десятками огромных и чудесных имений, разбросанных по России и Азии, снабженных библиотеками, лабораториями, картинными галереями, и, насколько можно было понять, являлось одной из наиболее мощных творческих сил страны. Алексея поразили строгие

станциях, опытном поле и ферме все завоевания русской и западно-европейской науки и ныне дающее эти агрономические знания нашему земледелию в лице тысячи обучающихся в ней студентов» (Чаянов 2008б: 25). 
правила устава, почти монастырского по типу, и та сияющая, звенящая радость, которая пропитывала все кругом» (Чаянов 2006в: 237).

Жизнь студентов утопического «братства Флора и Лавра» проходит в непосредственном соприкосновении с культурой XIX века: «В анфиладе комнат старого дворца и липовых аллеях парка, освещенных былыми посещениями Пушкина и блистательной, галантной жизнью Бориса Николаевича Юсупова с его вольтерьянством и колоссальной библиотекой, посвященной французской революции и кулинарии, шумела юная толпа носителей прометеева огня творчества, делившая труды с радостями жизни» (Чаянов 2006в: 236). Как отмечал ученый в своей методической статье, «главнейшее, что дает высшая школа, — это особая, ей одной присущая культура. Питомец высшей школы среди обывателей подобен магометанину, побывавшему в Мекке, среди других магометан. Его кругозор широк, он лучше видит, он быстрее и шире мыслит» (Чаянов 2006б: 632). Выпускник, который «многие часы простаивал перед диковинными видениями Рембрандта и Боттичелли в Румянцевском музее, $<$...> слышал вдохновенную речь Станиславского и навеки сохранил в своей душе образы студии Художественного театра $<. .>$, приобщился к первоисточникам культуры, дохнул воздухом вершин человеческой мысли и искусств» (Чаянов 2006б: 641). Знакомство с передовыми научными технологиями и произведениями искусства способствует тому, что в душе студента загорается «тот Прометеев огонь, который неугасимо пылает в храме науки» (Чаянов 2006б: 631). Характерно, что в реальной Тимирязевской академии с 1922 года работал литературный кружок им. Брюсова, а в 1930-е годы им руководил В. П. Катаев (Кузнецов 1963: 82).

Историко-культурное значение усадьбы Архангельское, ее уникальная музейная коллекция, проекты, связанные с использованием этого поместья, вероятно, также стали отправной точкой для создания образа светского монастыря-университета. Как писал К. Г. Боленко, «можно сказать, что если многие усадьбы провоцировали появление утопий, обращенных в прошлое, то Архангельское в его предреволюционном состоянии провоцировало хозяев на создание проектов, обращенных в будущее или в равной степени в прошлое и будущее» (Боленко 2020).

Хозяева Архангельского - 3. Н. Юсупова с мужем (Ф. Ф. Сумароков-Эльстон, князь Юсупов) в 1900 г. в случае внезапного пресечения рода завещали свои коллекции, находившиеся в Архангельском, государству, а саму усадьбу, дворцы в Москве и в Санкт-Петербурге «в распоряжение его величества государя императора», чтобы они «избегли бы участи служить целям и интересам, противным их историческому прошлому» (Уточкина 1999: 168).

Их сын Ф. Ф. Юсупов «мечтал сделать из Архангельского художественный центр, построив в окрестностях целую серию жилищ, в том же стиле для художников, музыкантов, писателей, артистов. Там была 
бы академия, консерватория и театр» (Юсупов 1993: 96-97). Дворец он хотел сделать музеем, оставив несколько комнат для будущих выставок.

«Усадебный» текст в творчестве Чаянова тесно связан с его профессиональной деятельностью, работой по сохранению наследия прошлых эпох, интересом к истории Москвы, футурологическим проектам, моделирующим общественное использование культурных ценностей дворянских поместий.

Еще одной «реальной» гранью «усадебной» темы в жизни Чаянова можно считать его дачную жизнь в подмосковной Николиной Горе, в поселке кооператива работников Академии наук и искусства. Еще в 1923 году в письме к Е. Д. Кусковой он пессимистично говорил, что «если не будет перспектив, то невольно думается о преодолении себя и переходе где-нибудь, хотя бы в Литве, хотя бы в Эстонии, на хозяйственный труд». (Чаянов 2008в: 194-197). Вероятно, Чаянову было близко представление о сочетании умственного и физического труда, современники вспоминали, как он любил дачный быт. Сохранились фотография 1929 года, где Чаянов с женой и двумя детьми проводит лето на даче в поселке на Николиной Горе, а также снимок с соседями по даче.

Во время строительства дачных домов на участках все время находили артефакты минувших эпох, были начаты археологические раскопки, которыми руководил Чаянов. Например, на участке художника А. И. Кравченко, иллюстратора ряда повестей писателя, была когда-то старинная крепость, окруженная воротами. Таким образом, интерес Чаянова к истории получал практическую реализацию.

В научной, общественной, искусствоведческой работе Чаянова внимание к феномену дворянской усадьбы XIX века всегда было пристальным. Участие в деятельности Комитета по охране художественных сокровищ, создание историко-литературного путеводителя по ПетровскоРазумовскому, моделирование возможного использования старинных поместий в утопии - все это части одной работы по сохранению культурного наследия прошлого и интеграции его в современность. Неслучайно и в дачной жизни писателя, некоторой вариации усадебного быта, также проявился интерес к минувшим эпохам, связанный с археологической историей важного для него места.

\section{ЛИТЕРАТУРА}

Боленко Константин. «Усадьба Архангельское в литературе конца XIX — первой трети XX века: история возвращения». Русская словесность 6 (2020): 99-106.

«Краткий отчет о деятельности комитета по охране культурных и художественных сокровищ России». Кооперация и искусство. М.: Типография Н. А. Сазоновой, 1919: 65-79.

Кузнецов Алексей. Литературное Петровско-Разумовское (Страницы хроники). М.: Московский рабочий, 1963. 
Романов Николай. «Искусство и кооперация». Кооперация и искусство. М.: Типография Н. А. Сазоновой, 1919: 17-23.

Уточкина Ольга. «Юсуповы в России и для России. Юсуповский дворец». Дворянские особняки. История роgа, усаgьбы и коллекиии / Под общей ред. Г. И. Свешниковой. СПб., 1999: 353-367.

Чаянов Александр. «Кооперация и художественная культура России». Коопераиия и искусство. М.: Типография Н. А. Сазоновой, 1919: 11-16.

Чаянов Александр. «Лёлина книжка». Чаянов Александр. Московская гофманиаgа/ Послесловие В. Б. Муравьева; Примечания В. Б. Муравьева, С. Б. Фроловой. М.: Издательский Дом ТОНЧУ, 2006а: 9-34.

Чаянов Александр. «Методы высшего образования». Экономическое наслеgие А. В. Чаянова. М.: Издательский Дом ТОНЧУ, 2006б: 645-663.

Чаянов Александр. «Путешествие моего брата Алексея в страну крестьянской утопии». Чаянов Александр. Московская гофманиаgа/Послесловие В. Б. Муравьева; Примечания В. Б. Муравьева, С. Б. Фроловой. М.: Издательский Дом ТОНЧУ, 2006: 217-274.

Чаянов Александр. «Парки и аграрная реформа». Чаянов Александр. Избранное: Статьи о Москве. Письма (1909-1936) / Примечания С. Б. Фроловой. М.: Издательский Дом ТОНЧУ, 2008а: 108-110.

Чаянов Александр. «Петровско-Разумовское в его прошлом и настоящем». Чаянов Александр. Избранное: Статьи о Москве. Письма (1909-1936)/Примечания С. Б. Фроловой. М.: Издательский Дом ТОНЧУ, 2008б: 24-275.

Чаянов Александр. «Письма (1909-1936)». Чаянов Александр. Избранное: Статьи о Москве. Письма (1909-1936) /Примечания С. Б. Фроловой. М.: Издательский Дом ТОНЧУ, 2008в: 148-275.

Юсупов Феликс. Переg изгнанием. 1887-1919/Пер. с фр. О. Эдельман; Вступл., прим., публ. писем Н. Стрижовой. М.: Моск. центр искусств, 1993.

\section{LITERATURE}

Bolenko Konstantin. «Usad'ba Arhangel'skoe v literature kontsa XIX — pervoi treti XX veka: istoriia vozvrascheniia». Russkaia slovesnost' 6 (2020): 99-106.

Chaianov Aleksandr. «Kooperatsiia i hudozhestvennaia kul'tura Rossii». Kooperatsiia i iskusstvo. M.: Tipografiia N. A. Sazonovoi, 1919: 11-16.

Chaianov Aleksandr. «Lyolina knizhka». Aleksandr Chaianov. Moskovskaia gofmaniada / Posleslovie V. B. Murav'eva; Primechaniia V. B. Murav'eva, S. B. Frolovoi. M.: Izdatel'skii Dom TONCHU, 2006a: 9-34.

Chaianov Aleksandr. «Metody vysshego obrazovaniia». Ekonomicheskoe nasledie A. V. Chaianova. M.: Izdatel'skii Dom TONCHU, 2006b: 645-663.

Chaianov Aleksandr. «Puteshestvie moego brata Alekseia v stranu krest'ianskoi utopii». Chaianov Aleksandr. Moskovskaia gofmaniada/Posleslovie V. B. Murav'eva; Primechaniia V. B. Murav'eva, S. B. Frolovoi. M.: Izdatel'skii Dom TONCHU, 2006v: 217-274

Chaianov Aleksandr. «Parki i agrarnaia reforma». Aleksandr Chaianov. Izbrannoe: Stat' i o Moskve. Pis'ma (1909-1936) / Primechaniia S. B. Frolovoi. M.: Izdatel'skii Dom TONCHU, 2008a: $108-110$.

Chaianov Aleksandr. «Petrovsko-Razumovskoe v ego proshlom i nastoiaschem». Aleksandr Chaianov. Izbrannoe: Stat'i o Moskve. Pis'ma (1909-1936) / Primechaniia S. B. Frolovoi. M.: Izdatel'skii Dom TONCHU, 2008b: 24-275.

Chaianov Aleksandr. «Pis'ma (1909-1936)». Aleksandr Chaianov. Izbrannoe: Stat'i o Moskve. Pis'ma (1909-1936) / Primechaniia S. B. Frolovoi. M.: Izdatel'skii Dom TONCHU, 2008v: $148-275$.

Iusupov Feliks. Pered izgnaniem. 1887-1919/ Per. s fr. O. Edel'man; Vstupl., prim., publ. pisem N. Strizhovoi. M.: Mosk. tsentr iskusstv, 1993. 
«Kratkii otchet o deiatel'nosti komiteta po ohrane kul'turnyh i hudozhestvennyh sokrovisch Rossii». Kooperatsiia i iskusstvo. M.: Tipografiia N. A. Sazonovoi, 1919: 65-79.

Kuznetsov Aleksei. Literaturnoe Petrovsko-Razumovskoe (Stranitsy hroniki). M.: Moskovskii rabochii, 1963.

Romanov Nikolai. «Iskusstvo i kooperatsiia». Kooperatsiia i iskusstvo. M.: Tipografiia N. A. Sazonovoi, 1919: 17-23.

Utochkina Ol'ga. «Iusupovy v Rossii i dlia Rossii. Iusupovskii dvorets». Dvorianskie osobniaki. Istoriia roda, usad'by i kollektsii/Pod obschei red. G. I. Sveshnikovoi. SPb., 1999: 353-367.

Наталија Михаљенко

ИМАЮЕ У СТВАРАЛАШТВУ А. В. ЧАЈАНОВА — КњИЖЕВНО И РЕАЛНО

\section{Резиме}

Мотив „имања“ у књижевном стваралаштву А. В. Чајанова, светски признатог научника-економисте, дубински је повезан са његовим научним, друштвеним и уметничко-теоријским радом. Сарадња са „Комитетом за очување уметничког блага“, чија је активност била усмерена на очување културне баштине бивших властеоских имања; интересовање за историју имања „Петровско-Разумовско“, на којем је била организована Пољопривредна академија, у којој је радио Чајанов, као и разматрање футуролошких пројеката везаних за подмосковско имање Архангељско, вероватно је за последицу имало утицај на формирање уметничког лика манастира-универзитета „братства Флора и Лавра“" у Пуйовању мог брайа Алексеја у земљу сељачке уйойије. На материјалу књижевног текста остварене су идеје Чајанова о идеалној организацији живота и рада, која је била у тесној спрези са идејом „властеоске културе“ двадесетих година XIX века, као и са професионалним образовањем исто тако повезаним са усавршавањем у различитим сферама уметности.

Кључне речи: А. В. Чајанов, мотив „имања“, Пуйовағе мог̆ брайа Алексеја у земљу сељачке уйойије, утопија, имање Петровско-Разумовско. 